\title{
II. RESEÑAS
}

Acuña, Constanza. Ed. La curiosidad infinita de Athanasius Kircher. Una lectura a sus libros encontrados en la Biblioteca Nacional de Chile. Santiago: Ocholibros, 2012. 208 pp.

Cuánto más conocemos sobre Athanasius Kircher, menos logramos abarcarlo, como si las máscaras barrocas se sumaran para configurar un saber que, desde su propia construcción, carece de límites precisos, ya que abarca todo aquello que es creación divina y por ello también destino humano. El hallazgo de dieciocho libros originales en la Biblioteca Nacional de Chile es el punto de partida de la investigación que da origen a este libro y a la exposición La imagen barroca en la Biblioteca Nacional, inaugurada en diciembre del 2011, curada por Constanza Acuña, la editora de la publicación.

El apartado final del volumen permite aproximarnos al despliegue visual que acompañó la exhibición de los libros, que habían permanecido ocultos por siglos desde la expulsión de los jesuitas, sus últimos lectores. Unos selectos objetos indican desde dónde se propone leer, ahora, esta biblioteca develada: el San Francisco Javier yacente, obra de Jacobo Kellener, de la Catedral de Santiago; el mapa de América de Theodor De Bry; una custodia andina del siglo XVIII y boleadoras tehuelches. Nos ubican temporal y territorialmente, pero dos instalaciones activan la lectura para generar paralelismos contemporáneos: Demián Schopf interpreta Mundus subterraneus, una obra reactiva, donde juegan la causalidad de los sismos y las palabras, la ciencia y lo contingente, intenta revelar el mecanismo de asociación que sustenta el plan divino, entre lo geológico y lo humano, entre el lenguaje y lo experimental. En contrapunto a la vitrina de Schopf, los artistas Joaquín Cociña y Cristobal León elaboraron, en $16 \mathrm{~mm}$, un film que parte de la simpatía entre razón y fe para plantear el arca del futuro. Si las visiones del futuro siempre parecen pagar una deuda al pasado literario, aquí hay una sintonía estética: el futuro es de obligado barroquismo.

¿Por qué comenzar a pensar este libro sobre Kircher desde los artistas contemporáneos? Porque, sin duda, es desde las imágenes desde donde mejor podemos comprender el mundo de Kircher. Si las indagaciones más diversas sobre su figura se han activado aún más en la última década, en este caso se acoplan con el actual esplendor de los estudios sobre el barroco americano. La centralidad de Kircher en los ensayos ilumina la iconografía, la música, la exploración de la naturaleza, las redes intelectuales de los jesuitas entre Roma y el sur del continente, entre otras cuestiones.

Nicolás A. Trujillo Osorio entrega una correcta obertura, ya que en su presentación de la figura de Athanasius Kircher surgen los motivos que se retomarán en otros ensayos. No solo Trujillo cumple con el desafío de alcanzar el pensamiento del jesuita a un público no especializado, sino que lo logra desde la sutil correspondencia entre biografía, azar, 
curiosidad, visión mística y hermetismo. El "telón lleno de pliegues y vuelcos" de la Roma contrarreformista barroca es el escenario teatral donde hace actuar la ars combinatoria y la ambición desmesurada de alcanzar el conocimiento de todo.

Una de los episodios historiográficos más notables dentro de los estudios del barroco americano ocurrió hace unos veinte años: la interpretación de la iconografía de los arcángeles arcabuceros llevada a cabo por Ramón Mujica Pinilla y José Emilio Burucúa. Ambos llegaban a conclusiones similares desde lecturas compartidas, sin estar en contacto entre ellos. El ensayo actual de Burucúa es un nuevo capítulo en la larga conversación intelectual que busca descifrar aquella singularidad iconográfica del Altiplano. Ya entonces la referencia al Libro de Enoch, citado en Oedipus cegyptiacus, formaba parte de la cadena de argumentación sobre la influencia de la tradición hermética; ahora el hallazgo en la biblioteca de Santiago de los dos primeros volúmenes de la obra de Kircher otorga la prueba de su circulación americana, antes solo sospechada. Burucúa establece la relación entre el texto de Kircher y los ángeles arcabuceros en los pasajes del segundo tomo de los Phrontisterii o Gimnasio. Es sugerente la lectura de que, en la memoria de los jesuitas que idearon la iconografía de los arcángeles arcabuceros, perduraba la extensa cita de Kircher a la Philosophia de San Isaac de Nínive, con sus términos militares. La complejidad de la cultura jesuita se vislumbra en el sutil encadenamiento de arte de la memoria, interpretación cabalista y cosmologías que propone Burucúa: Kircher, Antonio Vieira y Manuel Lacunza.

En el tercer ensayo, Víctor Rondón explora las relaciones intelectuales entre Kircher y Alonso de Ovalle, ambos estudiosos de lo sonoro y lo musical, en un juego entre centro y periferia de la red jesuita. Al reconstruir la figura de Ovalle, establece una larga digresión en el texto: la intención precursora de Ovalle de traer operarios a Chile. También la relación entre Ovalle y Kircher es central en la argumentación del ensayo de Sandra Accatino, centrado en Ars magna lucis et umbrce y la Histórica relación del Reyno de Chile, publicados ambos en 1646. En particular sobresale el análisis del vínculo entre la Virgen en la Peña de Arauco y las anamorfosis del barroco romano. Imagen que deviene expresión tanto de la observación de la naturaleza-fundamentos de un método científico- como metáfora de la intervención divina.

La cuestión de cómo el conocimiento científico elaborado por Kircher se transformó en "metáforas más que en razones" es el nudo conceptual del análisis de Pablo Chiuminatto. El Arca de Noé y La Tierra de Babel son ejemplares del "método hermenéutico infinito" para reconstruir los orígenes de la historia humana. Kircher, comprueba Chiuminatto, presenta una necesidad iconográfica para sus explicaciones. Las imágenes de los libros de Kircher trasmiten una imaginación prodigiosa para entender los textos bíblicos, pero también una racionalidad constructiva, más la precisión alegórica del saber simbólico.

El ensayo de Constanza Acuña inicia con la afirmación de que la riqueza de las bibliotecas coloniales jesuitas permitió que, en el extremo del mundo, se formaran humanistas de la talla de Manuel Lacunza, Juan Ignacio Molina y Miguel de Olivares. Entre los propietarios iniciales de los libros, Acuña rescata la figura de Nicolás Mascardi, discípulo de Athanasius Kircher, que, estimulado por Alonso de Ovalle, se trasladó a América del Sur hacia 1632. Un conjunto de siete cartas subrayan el lazo entre Mascardi y su maestro; además, Acuña comprueba cómo este epistolario es relevante para el libro 
Mundus subterraneus de 1665. En el mismo sentido, comenta los intercambios entre Kircher y el sacerdote mexicano Alexandro Favián, de modo tal que se construye una red de estudiosos jesuitas para el conocimiento del mundo, cuyo centro es el gabinete romano. Las búsquedas de Mascardi en la Patagonia, entre las maravillas de la naturaleza y la Ciudad de los Césares, es un capítulo asombroso de esa ansiedad por el todo.

Fernando Pérez Villalón estudia China monumentis illustrata a partir de la manera en que "concibe y representa Kircher el lenguaje chino"; para ello, analiza el rasgo curioso de tratar de demostrar que la religión, la lengua y las costumbres provienen de Egipto. A pesar de la especificidad del objeto que estudia, Pérez Villalón logra confirmar estrategias, prácticas y métodos del pensamiento de Kircher, marcando de este modo la unidad conceptual de su búsqueda tenaz del conocimiento que afirme el plan divino, pero, principalmente, la noción de la escritura como imagen pictórica, que, aplicable al origen de los ideogramas chinos, sirve también para indagar en el corpus bibliográfico del jesuita.

Existen varias lecturas que convertirán a este libro en indispensable-como si el objeto de estudio, ese conjunto de dieciocho libros, afinase las combinaciones posibles- para revisitar el mundo jesuita chileno, donde cuentan el Altiplano y la Patagonia, Santiago y Roma; pero también para explorar la circulación de las imágenes y los textos que las originan -más complejo que el tópico sobre los grabados de la evangelización. La interpretación de los frontispicios de los libros de Kircher, por los diversos autores, puede conformar un bello folleto de complejas alegorías, condensación visual del ars combinatoria de Kircher, pero, especialmente, de clave sobre el plan divino, la conquista espiritual universal y el fin de los tiempos.

Tal vez la fascinación creciente con la obra de Kircher se deba a que el programa continúa inconcluso: alcanzar la armonía universal entre el universo, la naturaleza y los hombres.

RoBerto AMigo

Museo Nacional de Bellas Artes (Buenos Aires) Universidad Nacional General Sarmient / Universidad de Buenos Aires amigorob@hotmail.com 